\title{
Hydrocortisone decreases lethality and inflammatory cytokine and nitric oxide production in rats challenged with $B$. anthracis cell wall peptidoglycan
}

Yan Li ${ }^{1}$, Xizhong Cui ${ }^{1}$, Joseph Shiloach'², Jeffrey Wang ${ }^{1}$, Dante A. Suffredini ${ }^{3}$, Wanying X ${ }^{1}$, Wancang Liu ${ }^{2}$, Yvonne Fitz ${ }^{1}$, Junfeng Sun ${ }^{1}$ and Peter Q. Eichacker ${ }^{1 *}$ (D)

${ }^{*}$ Correspondence: peichacker@mail.cc.nih.gov ${ }^{1}$ Critical Care Medicine Department, NIH Clinical Center, National Institutes of Health, Building 10, Room 2C145, 10 Center Drive, Bethesda, MD 20892, USA Full list of author information is available at the end of the article

\begin{abstract}
Background: Lethal B. anthracis infection produces high proinflammatory peptidoglycan (PGN) burdens in hosts. We investigated whether the lethality and inflammation anthrax PGN can produce are related.

Methods: At $6 \mathrm{~h}$ before and the start of $24 \mathrm{~h}$ anthrax PGN infusions, rats $(n=198)$ were treated with diluent (controls) or one of three IV-doses of either hydrocortisone $(125,12.5$ or $1.25 \mathrm{mg} / \mathrm{kg}$ ) or TNF-soluble receptor (TNFsr; 2000,1000 or $333 \mu \mathrm{g} / \mathrm{kg}$ ), non-selective and selective anti-inflammatory agents, respectively.

Results: Compared to controls, hydrocortisone 125 and $12.5 \mathrm{mg} / \mathrm{kg}$ each decreased 7-day lethality ( $p \leq 0.004)$. Hydrocortisone $125 \mathrm{mg} / \mathrm{kg}$ decreased IL-1 $\beta$, IL-6, TNFa, MCP, MIP-1a, MIP-2, RANTES and nitric oxide (NO) blood levels at 4 and $24 \mathrm{~h}$ after starting PGN (except MCP at $24 \mathrm{~h}$ ). Each decrease was significant at $4 \mathrm{~h}$ (except MIP-1 a that was significant at $24 \mathrm{~h})(p \leq 0.05)$. Similarly, hydrocortisone $12.5 \mathrm{mg} / \mathrm{kg}$ decreased each measure at 4, 24 and $48 \mathrm{~h}$ (except TNFa at $24 \mathrm{~h}$ and MIP-1 $\mathrm{a}$ at 24 and $48 \mathrm{~h}$ and $\mathrm{NO}$ at $48 \mathrm{~h}$ ). Decreases were significant for IL-6 and NO at $4 \mathrm{~h}$ and RANTES at $48 \mathrm{~h}(p \leq 0.05)$. Hydrocortisone $1.25 \mathrm{mg} / \mathrm{kg}$ had non-significant effects. Each TNFsr dose decreased lethality but non-significantly. However, when doses were analyzed together, TNFsr decreased lethality in a potential trend $(p=0.16)$ and IL- 6 and NO significantly at $4 \mathrm{~h}$ $(p=0.05)$.
\end{abstract}

Conclusions: Peptidoglycan-stimulated host inflammation may contribute to $B$. anthracis lethality.

Keywords: B. anthracis, Shock, Cell wall, Peptidoglycan, Anti-inflammatory agents, Corticosteroids, TNF-soluble receptor

\section{Introduction}

Outbreaks and isolated cases of Bacillus anthracis (B. anthracis) infection in the United States and Europe over the past 15 years and this bacterium's weaponization potential, have raised persistent concerns [1-3]. Invasive forms of infection produce shock author(s) and the source, provide a link to the Creative Commons licence, and indicate if changes were made. The images or other third party material in this article are included in the article's Creative Commons licence, unless indicated otherwise in a credit line to the material. If material is not included in the article's Creative Commons licence and your intended use is not permitted by statutory regulation or exceeds the permitted use, you will need to obtain permission directly from the copyright holder. To view a copy of this licence, visit http:// creativecommons.org/licenses/by/4.0/. 
resistant to supportive measures and have a poor prognosis [3-5]. Anthrax lethal and edema toxin (LT and ET) have long been associated with $B$. anthracis lethality. Lethal toxin is a potent inhibitor of stress kinase pathways while ET has adenyl cyclase activity that increases intracellular cAMP to very high levels [3]. Both have the ability to produce shock and organ injury in animal models [6]. Notably though, shock and lethality with LT and ET have been shown not to be associated with the kind of systemic inflammatory response associated with bacterial sepsis $[7,8]$. However, increasing evidence suggests that the $B$. anthracis cell wall and its peptidoglycan (PGN) component may contribute to shock and lethality with this bacterium, in part by stimulating maladaptive inflammatory responses [5, 9]. Infusion of viable lethal $B$. anthracis in baboons produced increases in inflammatory cytokines, shock and organ injury [10]. We then showed that B. anthracis cell wall alone produced a similar inflammatory response and lethality in rats [11]. In a subsequent study we conducted comparing similarly lethal 24-h challenges of B. anthracis LT, ET or purified cell wall PGN in rats, only PGN produced significant increases in circulating inflammatory cytokine and nitric oxide levels and coagulopathy consistent with disseminated intravascular coagulation (DIC) [12]. The pattern and time course of these coagulopathic changes with anthrax PGN challenge were also noted in a baboon model by another group that has studied this component's inflammatory effects [13-16]. Although excessive inflammation is implicated in the pathogenesis of cell wall components from other bacteria, it may be more important during B. anthracis infection which produces exceptionally high bacteria burdens in blood and tissue and provides a potentially large PGN reservoir [17-19].

While it is clear B. anthracis PGN stimulates a host inflammatory response, whether this proinflammatory effect contributes to lethality and organ injury is unknown. To examine this question, we pre-treated Sprague-Dawley rats with high, medium or low doses of either hydrocortisone (HC), a nonselective anti-inflammatory agent, or tumor necrosis factor soluble receptor (TNFsr), a selective one. Rats were then challenged with 24-h anthrax PGN infusions to simulate its release during bacterial infection. We hypothesized that suppressing host inflammation, either non-selectively with $\mathrm{HC}$ or selectively with TNFsr, would reduce PGN-associated lethality, inflammatory cytokine levels, and organ injury.

\section{Methods}

\section{Animal care}

This study was approved by the Animal Care and Use Committee of the Clinical Center of the National Institutes of Health, protocol \#ASP CCM 1801.

\section{Study design}

Nineteen weekly experiments were performed examining either hydrocortisone (HC) or TNFsr (Additional file 1: Table S1). Male Sprague-Dawley rats ( $n=198$ total) weighing 250 to $300 \mathrm{~g}$ with indwelling carotid arterial and jugular venous catheters were challenged with an LD40 to LD80 dose of $B$. anthracis PGN infused over $24 \mathrm{~h}$ via the venous catheter. Three sets of weekly experiments examined either high, medium or low doses of HC $(125,12.5$ or $1.25 \mathrm{mg} / \mathrm{kg}$, respectively) and three other sets examined high, medium or low doses of TNFsr (2000, 1000 or $333 \mu \mathrm{g} / \mathrm{kg}$, respectively). In each 
weekly experiment, animals were randomized to receive the dose of anti-inflammatory agent being studied ( $n=4$ to 6 ) or diluent (control, $n=4$ to 6 ) administered $6 \mathrm{~h}$ before (T-6) and at the time the PGN infusion was started (T0). From $6 \mathrm{~h}$ before until $48 \mathrm{~h}$ following the start of the PGN infusion, animals had mean arterial blood pressure (MBP) and heart rate (HR) continuously measured and data at $3 \mathrm{~h}$ intervals was analyzed. At 4, 24 and $48 \mathrm{~h}$ after the start of PGN, $0.5 \mathrm{ml}$ blood was drawn from the arterial catheter for measurement of seven cytokines (IL-1 $\beta$, IL-6, TNF $\alpha$, MIP-1 $\alpha$, MIP-2, MCP-1 and RANTES), nitric oxide (NO), complete blood count (CBC), arterial blood gas (ABG) with lactate, and chemistries with $\mathrm{Na}, \mathrm{K}, \mathrm{Cl}$, alanine and aspartate amino-transferases (ALT and AST), creatine phosphokinase (CK) and blood urea nitrogen (BUN) and creatinine $(\mathrm{Cr})$. Sampled blood was replaced with saline $0.5 \mathrm{ml}$. Animals alive following $168 \mathrm{~h}$ of observation were considered survivors and were euthanized. This study was initially designed to only include hemodynamic measures for $24 \mathrm{~h}$. But after experiments testing the hydrocortisone dose $125 \mathrm{mg} / \mathrm{kg}$ were completed, a decision was made to extend these measures until $48 \mathrm{~h}$.

\section{Peptidoglycan and treatment preparation and dosing}

Peptidoglycan was isolated and prepared from B. anthracis strain $\Delta$ Sterne strain, which lacks capsule and toxins, as previously described $[14,16]$. Briefly, bacteria grown overnight on tryptic soy broth plates were boiled in $8 \%$ SDS for $30 \mathrm{~min}$ and centrifuged. The pellet was washed with endotoxin-free water and subjected to DNase I and RNase A treatment. The sample was boiled in 4\% SDS for $30 \mathrm{~min}$ and washed three times with endotoxin-free water. The pellet was then treated with $\mathrm{NaCl} 2 \mathrm{M}$, washed six times with endotoxin-free water, dried, weighed, resuspended in endotoxin-free water and treated with hydrofluoric acid (HF) to remove the PGN-associated polysaccharide [20]. Following HF treatment, the PGN was treated with a denaturing buffer $[50 \mathrm{mM}$ Tris $(\mathrm{pH}$ 8.0), $6 \mathrm{M}$ guanidine $\mathrm{HCl}, 25 \mathrm{mM}$ dithiothreitol (DTT)] at $60{ }^{\circ} \mathrm{C}$ for $1 \mathrm{~h}$. Iodoacetamide $75 \mathrm{mM}$ was added and the preparation was incubated for $15 \mathrm{~min}$ in the dark to alkylate Cys residues. The reaction was stopped with DTT $40 \mathrm{mM}$. The PGN was resuspended in a buffer containing $50 \mathrm{mM}$ Tris (pH 7.5), $1 \mathrm{M}$ guanidine $\mathrm{HCl}$, and $5 \mathrm{mM} \mathrm{CaCl}_{2}$ and was treated with $20 \mu \mathrm{g}$ proteinase $\mathrm{K}$, added every $12 \mathrm{~h}$ for $36 \mathrm{~h}$ at $50{ }^{\circ} \mathrm{C}$. Finally, the PGN was washed three times with endotoxin-free water, dried, weighed, and resuspended in endotoxin-free water when used. It required $1.7 \times 10^{10} \mathrm{CFU}$ to produce $1 \mathrm{mg}$ of purified PGN. The methods were previously shown to produce preparations free of other PGN binding molecules [12].

Three separate batches of PGN were employed for each dose of hydrocortisone investigated (i.e., one batch for each dose) and one batch for all TNFsr doses studied. Following preparation of each PGN batch, a survival dose response study was performed, and the PGN dose producing a lethality rate of 40 to $80 \%$ was employed in subsequent experiments. This dose was found to be $80 \mathrm{mg} / \mathrm{kg}$ administered at $3.3 \mathrm{mg} / \mathrm{kg} / \mathrm{h}$ for $24 \mathrm{~h}$ for all experiments. As determined by the chromogenic limulus amoebocyte lysate assay (Clonogen, Germantown, MD) the lipopolysaccharide (LPS) content for each PGN preparation was $\leq 1.9 \mathrm{ng} / \mathrm{mg}$ and the LPS amount administered during a $24 \mathrm{~h}$ infusion of PGN for the average size animal studied was $\leq 152 \mathrm{ng} / \mathrm{kg}$. Compared to diluent control rats $(n=6)$, a $24 \mathrm{~h}$ LPS infusion of $160 \mathrm{ng} / \mathrm{kg}$ in animals $(n=6)$ produced no lethality and 
did not significantly increase IL-1 $\beta$, IL-6, TNF $\alpha$, MIP- $1 \alpha$, MIP-2, MCP-1, RANTES or $\mathrm{NO}$ at 4 or $24 \mathrm{~h}$ after the start of challenge (except MIP1 $\alpha$ at $4 \mathrm{~h}, p=0.007$ ). By contrast, compared to another group of diluent controls $(n=14)$, a 24 h PGN infusion of $80 \mathrm{mg} /$ $\mathrm{kg}(n=12)$ produced $50 \%$ lethality and significant increases in each of these parameters at $4 \mathrm{~h}(p=0.005)$ and in IL-1 $\beta$, MCP-1, MIP- $1 \alpha$, MIP-2 and NO at $24 \mathrm{~h}(p \leq 0.009)$.

Based on a factor of 0.162 to convert animal to human dosing, the HC 125, 12.5 or $1.25 \mathrm{mg} / \mathrm{kg}$ doses administered at T-6 and T0 in rats in these experiments would be equivalent to total doses in a $70 \mathrm{~kg}$ human of 2800,280 , and $28 \mathrm{mg}$ [21]. These doses are comparable to a pulse, stress or maintenance $\mathrm{HC}$ dose, respectively, administered clinically [22-25]. The doses of TNFsr investigated here in rats (2000, 1000 and $333 \mu \mathrm{g} /$ $\mathrm{kg}$ administered at T-6 and T0) would be equivalent to total doses in a $70 \mathrm{~kg}$ human of $45.4,22.7$, and $7.4 \mathrm{mg}$. The two higher TNFsr doses studied are equivalent to the 50 and $25 \mathrm{mg}$ doses recommended for humans with rheumatologic disease [26, 27]. The dose of $333 \mu \mathrm{g} / \mathrm{kg}$ employed here was greater than a dose of $250 \mu \mathrm{g} / \mathrm{kg}$ we previously showed was protective in rats challenged with lethal intravenous and intrabronchial $E$. coli challenges [28].

\section{Laboratory measures}

As previously described, protected catheters were attached to exteriorized arterial and central venous access ports on each animal [7]. Central venous catheters were attached via 3-way stop-cocks to a syringe pump to provide PGN as an infusion. Arterial catheters were connected to transducers to determine arterial blood pressure and heart rates. Arterial blood was collected for $\mathrm{CBC}, \mathrm{ABG}$ and lactate, chemistry, cytokine and nitric oxide measures. Cytokine (IL- $1 \beta$, IL-6, TNF $\alpha$, MIP- $1 \alpha$, MIP-2, MCP-1 and RANTES) and NO levels and $C B C$ and $A B G$ were determined as previously described [12, 28].

\section{Statistics}

Survival times were plotted using Kaplan-Meier survival curves and analyzed using stratified log-rank tests and Cox proportional hazard model. For all other variables, we used linear mixed models to account for repeated measurements of each animal and the actual pairing of animals within each cycle. Standard residual diagnostics were used to check model assumptions. Due to limitations in the amount of purified PGN and animals available for study, the numbers of animals investigated with doses of either $\mathrm{HC}$ or TNFsr was based on whether there was a trend in efficacy noted in early experiments with each dose and the amount of PGN and animals available for study. Data were logtransformed when needed. SAS version 9.4 (Cary, NC) was used for all analyses. All p-values are two-sided.

\section{Results}

\section{Effects of hydrocortisone}

Compared to diluent controls, following initiation of PGN challenge, survival with hydrocortisone was increased significantly with the high $(125 \mathrm{mg} / \mathrm{kg})$ and medium $(12.5 \mathrm{mg} / \mathrm{kg}) \mathrm{HC}$ doses $[15$ survivors of 23 total controls (65.2\% survival) vs. 22 of $22 \mathrm{HC} 125 \mathrm{mg} / \mathrm{kg}$ animals (100\% survival), $p=0.004 ; 11$ of 23 controls $(47.8 \%$ survival) vs. 25 of $25 \mathrm{HC} 12.5 \mathrm{mg} / \mathrm{kg}$ animals (100\% survival), $p<0.0001$ ], but not with 
the lowest dose $(1.25 \mathrm{mg} / \mathrm{kg}$ ) [ 3 of 9 controls (33.3\% survival) vs. 5 of $11 \mathrm{HC}$ animals (45.5\% survival), $p=0.97$ ] (Fig. 1). Compared to controls, high-dose HC increased mean arterial blood pressure (MBP) from $3 \mathrm{~h}$ after its first administration until $21 \mathrm{~h}$ after the start of the PGN infusion $(p \leq 0.05)$. Medium-dose HC increased MBP at $12,15,27$ and $30 \mathrm{~h}$ after the start of PGN infusion $(p \leq 0.05)$. Low-dose HC did not alter MBP significantly ( $>0.05$ for all measures). Neither high nor medium-dose HC altered heart rate (HR) significantly although low-dose $\mathrm{HC}$ increased $\mathrm{HR}$ at 21, 30, 36, 39 , and $45 \mathrm{~h}$ after the start of PGN $(p \leq 0.05)$.

High and medium but not low-dose HC suppressed the intravascular inflammatory response stimulated by PGN. Compared to controls, after the start of PGN infusion, high-dose HC decreased all cytokines and NO at both 4 and $24 \mathrm{~h}$ (except for MCP-1 at $24 \mathrm{~h}$ ) and these decreases were significant for IL-1 $\beta$, IL-6, TNF $\alpha$, MCP-1, MIP-2, RANTES and NO at $4 \mathrm{~h}$ and for MIP- $1 \alpha$ at $24 \mathrm{~h}(p \leq 0.05)$ (Fig. 2, Additional file 1: Table S2). In a similar pattern, but less significantly, medium-dose $\mathrm{HC}$ decreased all cytokines and NO at 4, 24 and $48 \mathrm{~h}$ except for TNF $\alpha$ at $24 \mathrm{~h}$, MIP- $1 \alpha$ at 4 and $24 \mathrm{~h}$ and $\mathrm{NO}$ at $48 \mathrm{~h}$. These decreases in IL-6 and NO with medium-dose HC were significant at $4 \mathrm{~h}(p \leq 0.05)$. Different from high and medium-dose HC, low-dose HC was associated with non-significant increases in cytokines and NO levels at most time points

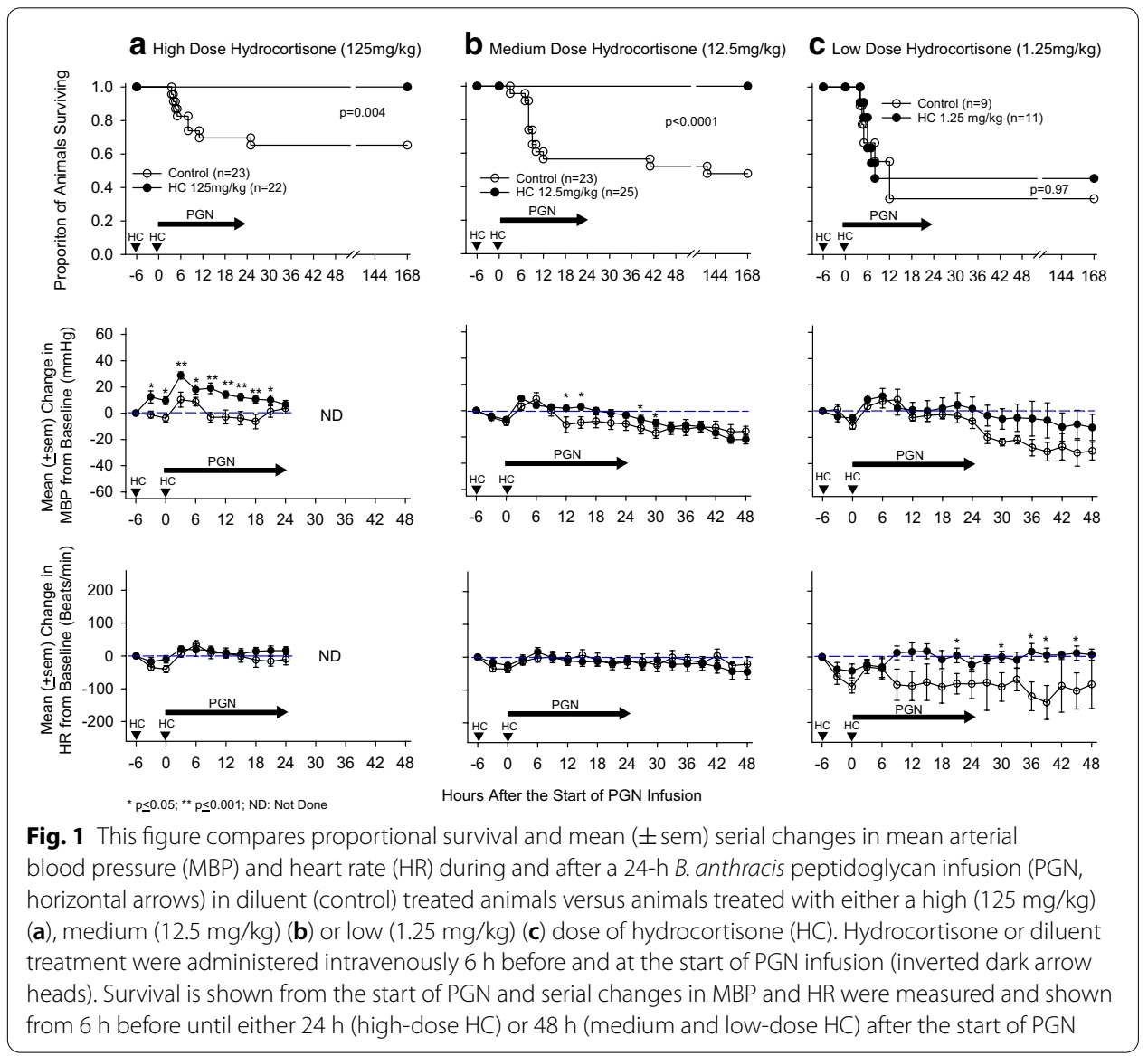




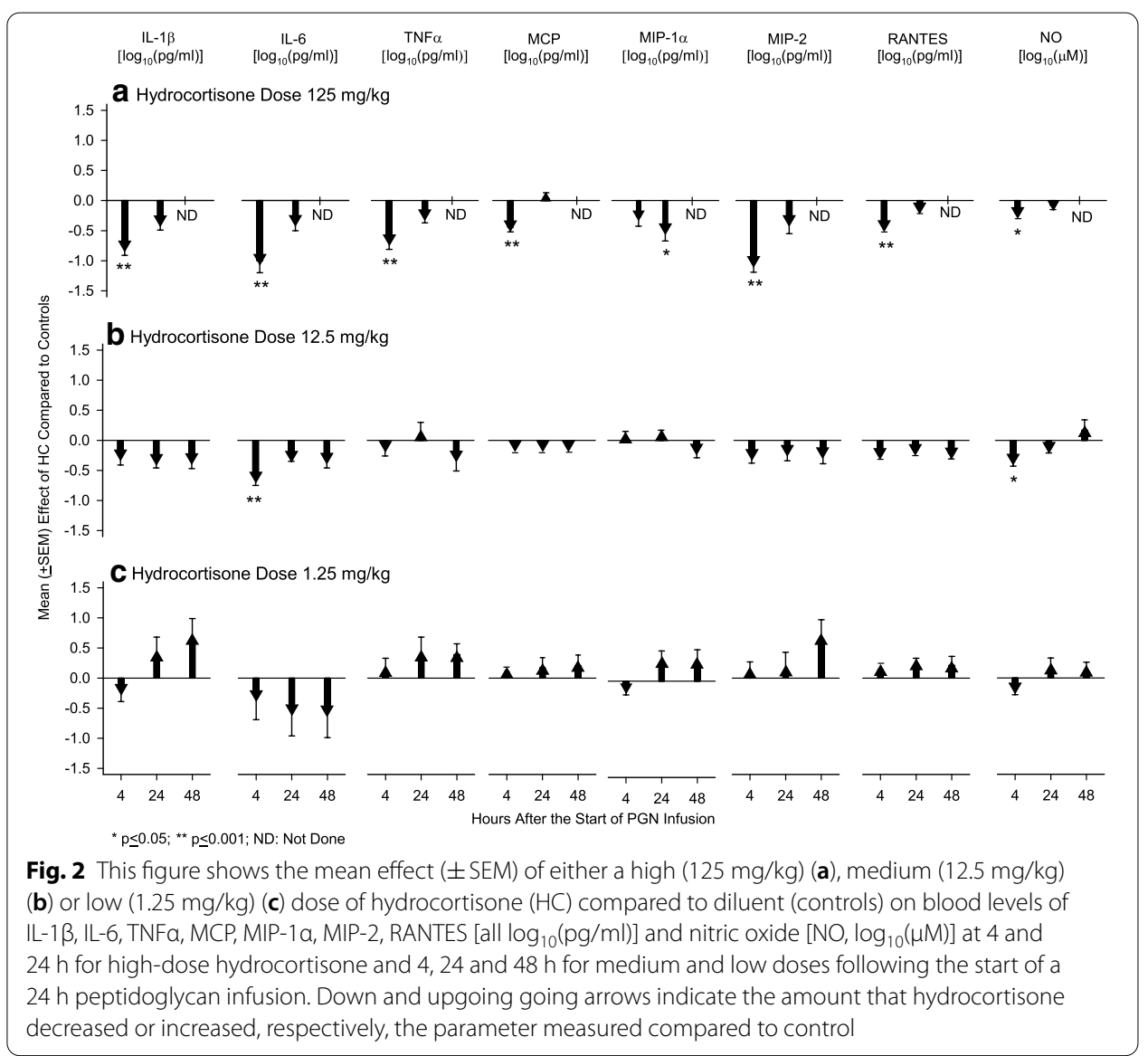

except for IL-1 $\beta$, MIP- $1 \alpha$ and NO at $4 \mathrm{~h}$ and IL- 6 at the three time points that had non-significant decreases.

Consistent with their effects on intravascular inflammatory markers, high and medium-dose $\mathrm{HC}$ inhibited evidence of liver and muscle injury caused by PGN. Compared to controls, high-dose HC significantly decreased alanine aminotransferase (ALT) at 4 and $24 \mathrm{~h}$, aspartate aminotransferase (AST) at $24 \mathrm{~h}$ and CK at $4 \mathrm{~h}(p \leq 0.05)$ (Fig. 3, Additional file 1: Table S3). Medium-dose HC decreased ALT, AST, and CK at 4,24 and $48 \mathrm{~h}$ and these decreases were significant for each parameter at $24 \mathrm{~h}$ $(p \leq 0.05)$ as well as when averaged over the three time points $(p \leq 0.01)$. Low-dose HC did not alter these parameters significantly ( $p>0.05$ for all).

Compared to controls, high and medium but not low-dose HC produced several other significant changes on measured parameters (Table 1 and Additional file 1: Table S4). Consistent with corticosteroid's hyperglycemic effects, high and mediumdose $\mathrm{HC}$ increased blood glucose at 4 or $24 \mathrm{~h}$, respectively $(p \leq 0.05)$. High-dose HC increased total circulating WBC, neutrophils and lymphocytes at $4 \mathrm{~h}$ and platelets at 4 and $24 \mathrm{~h}$ while medium-dose $\mathrm{HC}$ increased neutrophils at $4 \mathrm{~h}$, but decreased lymphocytes and total circulating WBC at $24 \mathrm{~h}(p \leq 0.05)$. High-dose HC decreased serum chloride at 4 and $24 \mathrm{~h}$ while medium dose increased chloride at $4 \mathrm{~h}$ and decreased blood urea nitrogen at $24 \mathrm{~h}(p \leq 0.05)$. High-dose $\mathrm{HC}$ increased arterial carbon 


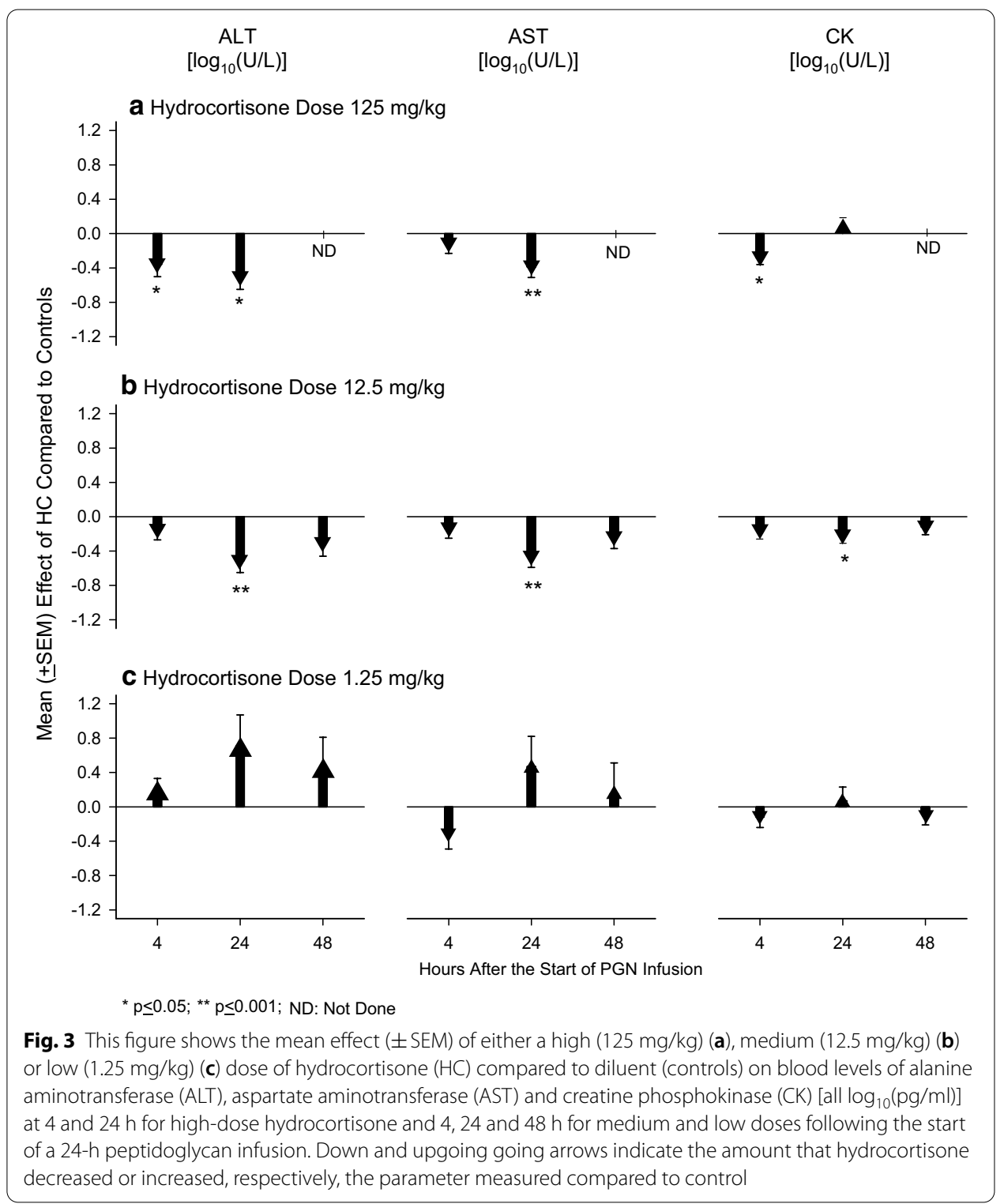

dioxide at 4 and $24 \mathrm{~h}$ and bicarbonate at $24 \mathrm{~h}$, while medium-dose $\mathrm{HC}$ decreased both measures at $4 \mathrm{~h} p \leq 0.05$ ).

\section{Effects of TNFsr}

Following initiation of PGN challenge, compared to diluent controls, survival was increased with each TNFsr dose, but none significantly as follows; high dose [3 survivors of 11 total controls (27.3\% survival) vs. 4 of 11 TNFsr $2000 \mu \mathrm{g} / \mathrm{kg}$ animals $(36.4 \%$ survival) $p=0.46$ ); medium dose [ 5 of 22 controls (22.7\% survival) vs. 6 of 22 TNFsr $1000 \mu \mathrm{g} / \mathrm{kg}$ animals (27.3\% survival), $p=0.26$ ]; and the low dose [ 1 of 9 controls (11.1\% survival) vs. 4 of $10 \mathrm{TNFsr} 333 \mu \mathrm{g} / \mathrm{kg}$ animals (40\% survival) $p=0.63$ ] (Additional file 1: Fig. S1). These survival effects were consistent and not significantly different comparing the three TNFsr doses $(p=0.98)$. Therefore, to increase the power to detect an effect 
Table 1 Mean ( \pm SEM) effect of high (125 mg/kg), medium (12.5 mg/kg), or low (1.25 mg/ kg) hydrocortisone compared to controls on glucose, leukocytes, platelets, creatinine, blood urea nitrogen, electrolytes, and arterial blood gas parameters at 4, 24 and $48 \mathrm{~h}$ after the start of peptidoglycan infusion

\begin{tabular}{|c|c|c|c|c|c|c|}
\hline $\begin{array}{l}\text { HC dose } \\
(\mathrm{mg} / \mathrm{kg})\end{array}$ & Time (h) & $\begin{array}{l}\text { Glucose } \\
{\left[\log _{10}(\mathrm{mg} / \mathrm{dl})\right]}\end{array}$ & $\begin{array}{l}\text { White } \\
\text { blood cells } \\
{\left[\log _{10}\left(\times 10^{3} / \mu \mathrm{l}\right)\right]}\end{array}$ & $\begin{array}{l}\text { Neutrophils } \\
{\left[\log _{10}\left(\times 10^{3} /\right.\right.} \\
\mu \mathrm{l})]\end{array}$ & $\begin{array}{l}\text { Lymphocytes } \\
{\left[\log _{10}\left(\times 10^{3} / \mu \mathrm{l}\right)\right]}\end{array}$ & $\begin{array}{l}\text { Platelets } \\
{\left[\log _{10}\left(\times 10^{3} /\right.\right.} \\
\mu \mathrm{l})]\end{array}$ \\
\hline \multirow[t]{3}{*}{125} & 4 & $0.20 \pm 0.07^{*}$ & $0.32 \pm 0.05^{* *}$ & $0.59 \pm 0.08^{* *}$ & $0.10 \pm 0.05^{*}$ & $0.13 \pm 0.06^{*}$ \\
\hline & 24 & $0.15 \pm 0.08$ & $0.03 \pm 0.06$ & $0.10 \pm 0.08$ & $0.001 \pm 0.05$ & $0.19 \pm 0.06^{*}$ \\
\hline & 48 & ND & ND & ND & ND & ND \\
\hline \multirow[t]{3}{*}{12.5} & 4 & $0.01 \pm 0.02$ & $0.06 \pm 0.06$ & $0.28 \pm 0.07^{* *}$ & $-0.04 \pm 0.06$ & $0.09 \pm 0.07$ \\
\hline & 24 & $0.05 \pm 0.02^{*}$ & $-0.18 \pm 0.06^{*}$ & $-0.14 \pm 0.08$ & $-0.17 \pm 0.07^{*}$ & $-0.07 \pm 0.07$ \\
\hline & 48 & $0.02 \pm 0.03$ & $-0.01 \pm 0.08$ & $0.11 \pm 0.10$ & $-0.05 \pm 0.09$ & $0.02 \pm 0.09$ \\
\hline \multirow[t]{4}{*}{1.25} & 4 & $0.10 \pm 0.07$ & $0.03 \pm 0.06$ & $-0.05 \pm 0.14$ & $0.08 \pm 0.07$ & $-0.41 \pm 0.19$ \\
\hline & 24 & $-0.08 \pm 0.08$ & $0.14 \pm 0.11$ & $0.10 \pm 0.18$ & $0.20 \pm 0.11$ & $-0.37 \pm 0.18$ \\
\hline & 48 & $-0.01 \pm 0.09$ & $-0.14 \pm 0.11$ & $0.02 \pm 0.18$ & $-0.13 \pm 0.12$ & $-0.41 \pm 0.19$ \\
\hline & & $\begin{array}{l}\text { Creatinine }(\mu \mathrm{g} / \\
\text { dl) }\end{array}$ & $\begin{array}{l}\text { BUN }\left[\log _{10}(\mathrm{mg} /\right. \\
\mathrm{dl})]\end{array}$ & $\mathrm{Na}(\mathrm{mmol} / \mathrm{l})$ & $\mathrm{K}(\mathrm{mmol} / \mathrm{l})$ & $\mathrm{Cl}(\mathrm{mmol} / \mathrm{l})$ \\
\hline \multirow[t]{3}{*}{125} & 4 & $47.1 \pm 37.8$ & $0.07 \pm 0.05$ & $-1.1 \pm 1.5$ & $-0.5 \pm 0.3$ & $-2.6 \pm 1.2^{*}$ \\
\hline & 24 & $64.1 \pm 40.4$ & $-0.07 \pm 0.06$ & $0.2 \pm 1.6$ & $-0.4 \pm 0.3$ & $-4.2 \pm 1.4^{*}$ \\
\hline & 48 & ND & ND & ND & ND & ND \\
\hline \multirow[t]{3}{*}{12.5} & 4 & $-65 \pm 89.1$ & $-0.02 \pm 0.04$ & $0.8 \pm 0.5$ & $-0.1 \pm 0.1$ & $1.9 \pm 0.6^{*}$ \\
\hline & 24 & $50.1 \pm 97$ & $-0.14 \pm 0.04^{*}$ & $-1.0 \pm 0.6$ & $0.03 \pm 0.11$ & $-0.1 \pm 0.7$ \\
\hline & 48 & ND & $-0.05 \pm 0.05$ & $-0.3 \pm 0.7$ & $0.2 \pm 0.1$ & $-0.1 \pm 0.9$ \\
\hline \multirow[t]{4}{*}{1.25} & 4 & $34.8 \pm 66.9$ & $-0.002 \pm 0.09$ & $0.6 \pm 1.2$ & $-0.4 \pm 0.4$ & $-0.34 \pm 1.5$ \\
\hline & 24 & $141.3 \pm 108.8$ & $0.11 \pm 0.15$ & $-0.3 \pm 1.9$ & $-0.2 \pm 0.6$ & $1.9 \pm 2.4$ \\
\hline & 48 & $-114.2 \pm 113.7$ & $0.11 \pm 0.15$ & $2.4 \pm 2.0$ & $-0.5 \pm 0.6$ & $2.1 \pm 2.5$ \\
\hline & & $\mathrm{pH}$ & $\mathrm{PCO}_{2}(\mathrm{mmHg})$ & $\mathrm{HCO}_{3}(\mathrm{mmol} / \mathrm{l})$ & $\begin{array}{l}\text { Lac } \\
{\left[\log _{10}(\mathrm{mmol} / \mathrm{l})\right]}\end{array}$ & $\mathrm{PO}_{2}(\mathrm{mmHg})$ \\
\hline \multirow[t]{3}{*}{125} & 4 & $-0.02 \pm 0.01$ & $2.4 \pm 0.9^{*}$ & $0.8 \pm 0.7$ & $-0.001 \pm 0.06$ & $-2.5 \pm 5.2$ \\
\hline & 24 & $0.001 \pm 0.01$ & $2.2 \pm 0.9^{*}$ & $2.1 \pm 0.7^{*}$ & $-0.09 \pm 0.07$ & $1.5 \pm 5.8$ \\
\hline & 48 & ND & ND & ND & ND & ND \\
\hline \multirow[t]{3}{*}{12.5} & 4 & $-0.001 \pm 0.01$ & $-1.9 \pm 0.6^{*}$ & $-1.5 \pm 0.4^{*}$ & $0.02 \pm 0.04$ & $1.5 \pm 3.3$ \\
\hline & 24 & $0.01 \pm 0.01$ & $-0.7 \pm 0.7$ & $0.02 \pm 0.4$ & $-0.05 \pm 0.05$ & $-3.8 \pm 3.9$ \\
\hline & 48 & $-0.01 \pm 0.01$ & $0.3 \pm 0.9$ & $-0.2 \pm 0.6$ & $-0.001 \pm 0.06$ & $0.4 \pm 5.1$ \\
\hline \multirow[t]{3}{*}{1.25} & 4 & $0.06 \pm 0.07$ & $-1.8 \pm 2.3$ & $1.2 \pm 1.6$ & $-0.05 \pm 0.16$ & $6.0 \pm 12.8$ \\
\hline & 24 & $0.01 \pm 0.08$ & $1.9 \pm 3.7$ & $-0.2 \pm 2.6$ & $0.12 \pm 0.22$ & $-2.0 \pm 16.1$ \\
\hline & 48 & $0.03 \pm 0.08$ & $0.9 \pm 3.9$ & $-0.1 \pm 2.7$ & $0.01 \pm 0.24$ & $-2.5 \pm 16.5$ \\
\hline
\end{tabular}

$\mathrm{HC}$, hydrocortisone; $\mathrm{BUN}$, blood urea nitrogen; $\mathrm{Na}$, sodium; $\mathrm{K}$, potassium; $\mathrm{Cl}$, chloride, $\mathrm{PaCO}_{2}$, arterial carbon dioxide; $\mathrm{HCO}_{3}$, bicarbonate; $\mathrm{PaO}_{2}$, arterial oxygen

${ }^{*} p \leq 0.05 ; * * 0.001$

related to this selective anti-inflammatory agent, survival and the results from all other parameters were averaged across TNFsr dose for all further analyses.

Overall, compared to controls, TNFsr did increase survival in a positive trend $(p=0.16)$, but did not alter MBP significantly at any time point ( $p>0.05$ for all) (Fig. 4). However, TNFsr did increase HR from 6 to $45 \mathrm{~h}$ after starting PGN and this was significant at $9 \mathrm{~h}(p=0.04)$. Notably, TNFsr was associated with decreases in cytokines and NO at most time points measured and decreases in IL- 6 and NO were both significant at $4 \mathrm{~h}$ ( $p \leq 0.05$, Fig. 4 and Additional file 1: Table S5). TNFsr also decreased [mean 


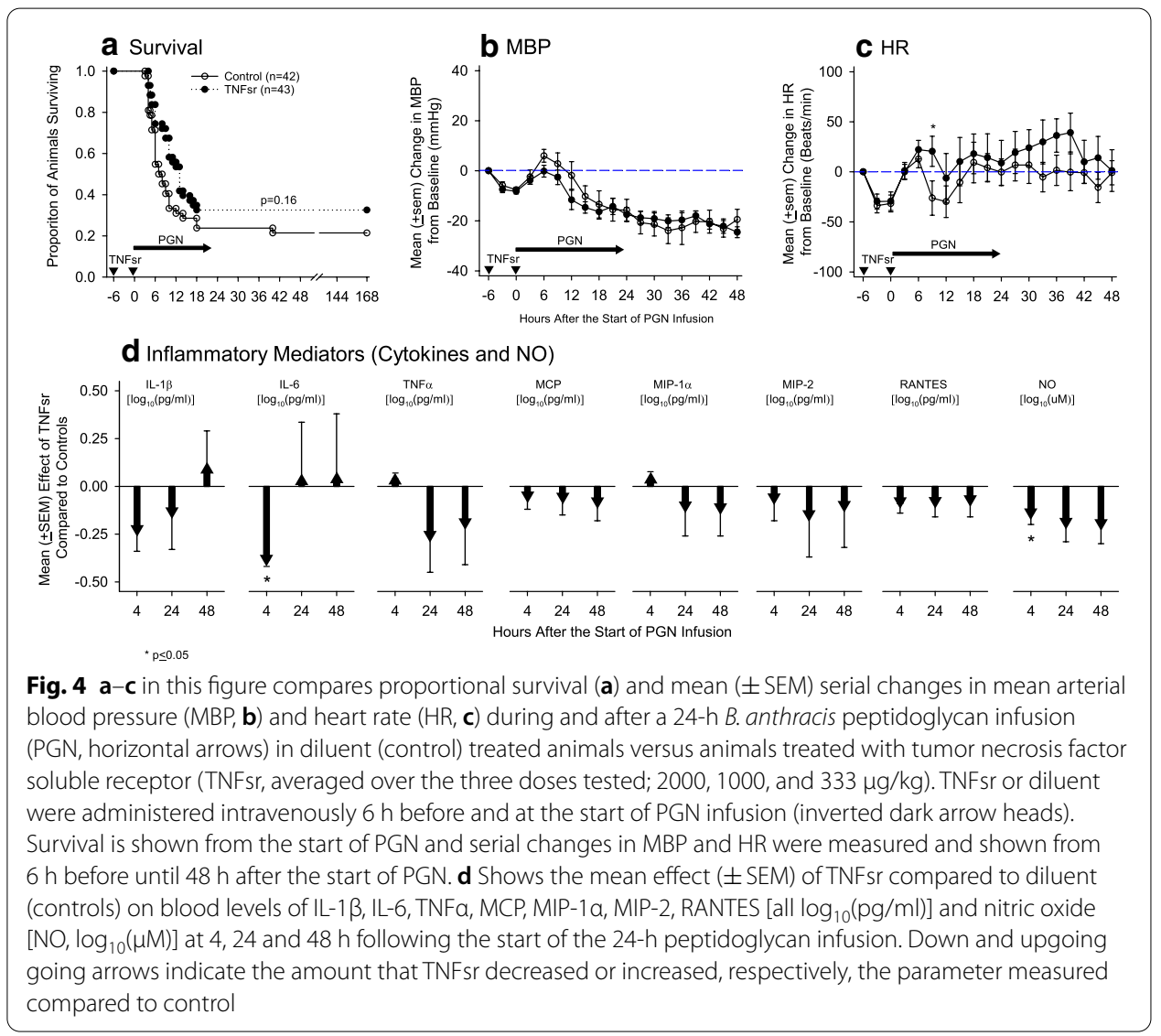

( \pm SEM) effect of TNFsr compared to control] lactate $\left[\log _{10}(\mathrm{mmol} / \mathrm{l})\right]$ at both 4 and $48 \mathrm{~h}$ $(-0.18 \pm 0.06$ and $-0.21 \pm 0.09)$ and increased serum sodium at $24 \mathrm{~h}(1.6 \pm 0.6 \mathrm{mmol} / \mathrm{l})$ $(p \leq 0.05$. Table 2 and Additional file 1: Table S6). Compared to controls, TNFsr did not alter any other parameter measured at any time point significantly $(p>0.05$ for all).

\section{Discussion}

Although an early maladaptive host inflammatory response has been closely associated with the pathogenesis of many lethal bacteria, its role during $B$. anthracis infection is unclear. Lethal and edema toxins appear central to the lethality of B. anthracis, but not only elicit little host inflammation, actually inhibit the innate immune response and may promote early infection [7, 29-31]. However, our present findings support the possibility that excessive host inflammation stimulated by $B$. anthracis PGN also contributes to this bacteria's lethality, an effect that may become stronger as the host's bacterial cell wall burden increases. High and medium-dose HC limited PGN-associated intravascular inflammatory cytokine and NO levels while improving survival, hemodynamic function and evidence of liver and muscle injury. Administration of TNFsr, a selective anti-inflammatory agent, had limited effects, but was associated with a trend towards increased survival and with early reductions in IL-6 and NO when examined across the three doses tested. 
Table 2 Mean ( \pm SEM) effect of TNFsr averaged over the three doses tested compared to controls on alanine and aspartate amino transferases, creatine phosphokinase, glucose, leukocytes, platelets, creatinine, blood urea nitrogen, electrolytes, and arterial blood gas parameters at 4, 24 and $48 \mathrm{~h}$ after the start of peptidoglycan infusion

\begin{tabular}{|c|c|c|c|c|c|c|}
\hline Time (h) & $\begin{array}{l}\text { ALT } \\
{\left[\log _{10}(U / I)\right]}\end{array}$ & $\begin{array}{l}\text { AST } \\
{\left[\log _{10}(U / I)\right]}\end{array}$ & CK $\left[\log _{10}(U / I)\right]$ & $\begin{array}{l}\text { Glucose } \\
{\left[\log _{10}(\mathrm{mg} / \mathrm{dl})\right]}\end{array}$ & $\begin{array}{l}\text { White } \\
\text { blood cells } \\
{\left[\log _{10}\left(\times 10^{3} /\right.\right.} \\
\mu \mathrm{l})]\end{array}$ & $\begin{array}{l}\text { Neutrophils } \\
{\left[\log _{10}\left(\times 10^{3} /\right.\right.} \\
\mu \mathrm{l})]\end{array}$ \\
\hline 4 & $-0.11 \pm 0.12$ & $-0.10 \pm 0.11$ & $-0.05 \pm 0.07$ & $-0.001 \pm 0.04$ & $0.03 \pm 0.04$ & $0.15 \pm 0.08$ \\
\hline 24 & $-0.05 \pm 0.22$ & $0.01 \pm 0.21$ & $0.03 \pm 0.13$ & $0.06 \pm 0.05$ & $0.12 \pm 0.08$ & $0.15 \pm 0.14$ \\
\hline \multirow[t]{2}{*}{48} & $0.03 \pm 0.23$ & $-0.10 \pm 0.22$ & $-0.08 \pm 0.13$ & $0.05 \pm 0.09$ & $-0.02 \pm 0.09$ & $-0.01 \pm 0.16$ \\
\hline & $\begin{array}{l}\text { Lymphocytes } \\
{\left[\log _{10}\left(\times 10^{3} /\right.\right.} \\
\mu \mathrm{l})]\end{array}$ & $\begin{array}{l}\text { Platelets } \\
{\left[\log _{10}\left(\times 10^{3} /\right.\right.} \\
\mu \mathrm{l})]\end{array}$ & $\begin{array}{l}\text { Creatinine } \\
(\mu \mathrm{g} / \mathrm{dl})\end{array}$ & $\begin{array}{l}\text { BUN } \\
{\left[\log _{10}(\mathrm{mg} / \mathrm{dl})\right]}\end{array}$ & $\mathrm{Na}(\mathrm{mmol} / \mathrm{l})$ & $\mathrm{K}(\mathrm{mmol} / \mathrm{l})$ \\
\hline 4 & $0.02 \pm 0.04$ & $0.04 \pm 0.07$ & $-20.4 \pm 40.7$ & $-0.03 \pm 0.04$ & $0.5 \pm 0.03$ & $-0.4 \pm 0.3$ \\
\hline 24 & $0.12 \pm 0.07$ & $0.23 \pm 0.12$ & $3.8 \pm 80.3$ & $0.08 \pm 0.07$ & $1.6 \pm 0.6^{*}$ & $-0.3 \pm 0.3$ \\
\hline \multirow[t]{2}{*}{48} & $0.004 \pm 0.09$ & $0.20 \pm 0.14$ & $35.7 \pm 83.1$ & $-0.04 \pm 0.07$ & $0.7 \pm 0.6$ & $-0.4 \pm 0.3$ \\
\hline & $\mathrm{Cl}(\mathrm{mmol} / \mathrm{l})$ & $\mathrm{pH}$ & $\begin{array}{l}\mathrm{PaCO}_{2} \\
(\mathrm{mmHg})\end{array}$ & $\begin{array}{l}\mathrm{HCO}_{3} \\
(\mathrm{mmol} / \mathrm{L})\end{array}$ & $\begin{array}{l}\text { Lactate } \\
{[\log (\mathrm{mmol} / \mathrm{L})]}\end{array}$ & $\mathrm{PaO}_{2}(\mathrm{mmHg})$ \\
\hline 4 & $0.2 \pm 0.5$ & $0.01 \pm 0.02$ & $2.1 \pm 1.3$ & $1.7 \pm 1.0$ & $-0.18 \pm 0.06^{*}$ & $-5.6 \pm 3.4$ \\
\hline 24 & $-0.1 \pm 1.0$ & $0.03 \pm 0.04$ & $-0.4 \pm 2.5$ & $1.9 \pm 1.7$ & $-0.03 \pm 0.09$ & $-1.3 \pm 6.4$ \\
\hline 48 & $1.0 \pm 1.0$ & $-0.02 \pm 0.04$ & $1.7 \pm 2.6$ & $1.7 \pm 1.7$ & $-0.21 \pm 0.09^{*}$ & $2.5 \pm 6.6$ \\
\hline
\end{tabular}

ALT and AST, alanine and aspartate aminotransferases; CK, creatine phosphokinase; BUN, blood urea nitrogen; $\mathrm{Na}$, sodium; $\mathrm{K}$, potassium; $\mathrm{Cl}$, chloride; $\mathrm{PaCO}_{2}$, arterial carbon dioxide; $\mathrm{HCO}_{3}$, bicarbonate; $\mathrm{PaO}_{2}$, arterial oxygen

${ }^{*} p \leq 0.05$

The effectiveness of high and medium-dose $\mathrm{HC}$ in the present study likely relates to the direct effect endogenous or exogenous glucocorticoids have on inhibiting nuclear factor- $\mathrm{\kappa} \beta(\mathrm{NF}-\mathrm{\kappa} \beta)$, a transcription factor central to host cell proinflammatory responses. Peptidoglycan from B. anthracis and other Gram-positive bacteria, is a glycan polymer composed of two alternating monomers: $\mathrm{N}$-acetylmuramic acid and $\mathrm{N}$-acetylglucosamine [32, 33]. These monomers are joined by short stem peptides $(4-5 \mathrm{~L}$ - and D-amino acids) that vary by bacteria type. The polymer also includes polysaccharides and lipoteichoic acid, both of which vary by bacteria type. Peptidoglycan and its components, together or individually, represent pathogen-associated molecular patterns (PAMPs) that can elicit innate and adaptive inflammatory responses via their interactions with immune cell membrane or cytosolic pattern-recognition receptors (PRRs) including toll-like receptor-2 (TLR-2), nucleotide-binding oligomerization domains 1 and 2 (NOD-1 and NOD-2), respectively, and cryopyrin [32-35]. These PRRs ultimately all signal through NF- $\kappa \beta$. Activation of NF- $\kappa \beta$ upregulates more than 100 genes including ones for all of the inflammatory cytokines and chemokines measured here as well as inducible NO synthase that generates NO [36-39]. Glucocorticoid binding to glucocorticoid receptor- $\alpha(G R \alpha)$ is a primary inhibitor of NF- $\kappa \beta$ and its downstream inflammatory effects [40-42].

Consistent with our prior and present studies, administration of S. aureus PGN and lipoteichoic acid in a rat model produced lethality (60\% mortality), increases in circulating TNF $\alpha$ and NO levels and hepatic injury [43]. Administration of dexamethasone $3 \mathrm{mg} / \mathrm{kg}$ (comparable to $\mathrm{HC} 75 \mathrm{mg} / \mathrm{kg}$ in the present model) $2 \mathrm{~h}$ before PGN challenge 
prevented lethality, increased blood pressure and reduced TNF $\alpha$ and NO levels and hepatic injury.

It is possible that high and medium-dose $\mathrm{HC}$ had protective effects here besides antiinflammatory ones. Hydrocortisone has mineralocorticoid effects which could have promoted sodium reabsorption and provided protective increases in intravascular volume. However, hemodynamic changes related to mineralocorticoids typically require several days to develop and sodium and potassium levels were not altered by high or medium-dose $\mathrm{HC}$ [44]. Alternatively, HC could have increased vascular smooth muscle responsiveness to endogenous catecholamines [44]. But blood pressure increases with the medium HC dose were not evident until after the start of PGN and its associated inflammatory cytokine and NO production.

We previously showed that $24 \mathrm{~h} \mathrm{~B}$. anthracis PGN infusions similar to the present study produced significant increases in TNF $\alpha$ levels at $6 \mathrm{~h}$ that persisted at non-significant levels at 24 and $48 \mathrm{~h}$ [12]. While TNFsr had effects on survival, IL-6 and NO in the present study that may implicate TNF in the lethal pathogenesis of B. anthracis PGN, this survival effect was far less pronounced than we observed with a lower TNFsr dose in E. coli challenged rats treated with antibiotics [28]. Lower TNFsr doses also improved survival significantly in antibiotic-treated mice challenged with $S$. aureus [45]. One interpretation of these findings is that other bacterial components present during a live bacterial challenge elicit lethal responses which are more TNF $\alpha$ dependent than with PGN alone.

Although this study suggests that host inflammatory mediator release is related to the lethal effects of $B$. anthracis PGN, it was not designed to investigate whether anti-inflammatory agents like $\mathrm{HC}$ or TNFsr have a therapeutic role. With the present model, such a study would have required anti-inflammatory agents be started no earlier than the start of the PGN infusion, and ideally sometime following that to simulate a patient with progressive infection. Furthermore, the potential adverse inhibitory effects of these agents on host defense and microbial clearance could only be tested in a model of live bacterial infection that would ideally also include antibiotic and other standard therapies. However, the present findings do have clinical implications. Patients progressing to severe anthrax infection have extensive extravascular fluid accumulation manifested as pleural and peritoneal effusions and tissue edema [4, 17, 46, 47]. Even though evidence suggests that lethal toxin disrupts endothelial barrier function, PGN-stimulated intravascular inflammation and coagulopathy could also contribute to this endothelial dysfunction $[46,48,49]$. Such inflammation is known to disrupt endothelial gap junction function and allows extravasation of protein and fluid [50,51]. Consistent with that, $B$. anthracis PGN administration in baboons was shown to disrupt endothelial gap junctions and increase vascular permeability measured with fluorescent labeled albumin [15]. At this time, based only on several small observational clinical studies, the CDC recommends consideration of corticosteroid use in patients with head and neck B. anthracis infection producing compromising edema of the airway [52]. The present findings are the first preclinical evidence we are aware of to provide support for this CDC recommendation.

In this and our previous present study, a highly lethal PGN dose infused over $24 \mathrm{~h}$ produced an early increase in circulating inflammatory cytokines that gradually subsided over 24 to $48 \mathrm{~h}$. Under these conditions, HC and TNFsr had anti-inflammatory effects 
with beneficial effects on survival and organ injury. However, PGN, like lipopolysaccharide, under come conditions, has been shown to have immunosuppressive effects and may actually augment host defenses [53,54]. Treatment strategies targeting PGN with $B$. anthracis or other Gram-positive bacteria, must account for the conditions under which this cell wall component elicits maladaptive harmful as opposed to adaptive beneficial host responses.

This study has limitations. First, it is unknown how the concentration of PGN employed in the present study relates to the levels occurring during live $B$. anthracis infection. The doses we employed in this and our prior study are comparable though to doses of $B$. anthracis PGN employed in a baboon model $[12,15]$. Challenge with PGN in that model simulated changes associated with live $B$. anthracis challenge in a similar non-human primate model [7]. Second, the PGN preparation used here had very small amounts of LPS contamination. However, an LPS concentration greater than the highest level in the PGN batches employed produced no lethality and no significant changes in any of the same inflammatory markers measured in the HC and TNFsr experiments except for one. By contrast, the dose of PGN employed produced highly significant changes in all of these measures. Third, limitations on animal numbers and purified PGN prevented formal power analysis calculations for experiments as well as testing whether larger sample sizes or a wider range of treatment doses would provide stronger evidence regarding the effects of TNFsr or the lowest $\mathrm{HC}$ dose investigated. These restrictions also prevented determining whether $\mathrm{HC}$ or TNFs had inhibitory effects on PGN-associated coagulopathy, tests which would have required additional PGN and animals for sampling. This limitation also prevented further exploration of a basis for the possible trend in survival and its associated inflammatory response noted with the lowest TNFsr dose studied. Fourth, blood measures with high-dose HC were only obtained over $24 \mathrm{~h}$ and the treatment's effects on inflammatory mediators at $48 \mathrm{~h}$ are unclear. Finally, this model tested PGN alone, and as stated above, both LT and ET can inhibit components in the innate immune response which could alter the effectiveness of anti-inflammatory therapies themselves.

\section{Conclusion}

Invasive $B$. anthracis infection is associated with resistant shock and high lethality rates. While evidence supports the role LT and ET have in this lethality, these toxins do not produce the excessive intravascular inflammatory response observed in animals challenged with lethal $B$. anthracis doses. The present findings support the possibility that inflammation caused by $B$. anthracis cell wall PGN has lethal effects. The high bacterial loads patients and animals dying with $B$. anthracis provide a large PGN source. Further studies are necessary to determine whether anti-inflammatory agents like $\mathrm{HC}$ or more selective ones, add to the protective effects of standard and toxin directed therapies during B. anthracis infection itself.

\section{Disclaimer}

The opinions expressed in this article are those of the authors and do not represent any position or policy of the National Institutes of Health, the US Department of Health and Human Services, or the US government. 


\section{Supplementary information}

Supplementary information accompanies this paper at https://doi.org/10.1186/s40635-020-00358-4.

Additional file 1. Additional tables and figure.

\section{Abbreviations}

PGN: Peptidoglycan; IV: Intravenous; HC: Hydrocortisone; TNFsr: Tumor necrosis factor soluble receptor; LT: Lethal toxin; ET: Edema toxin; MBP: Mean arterial blood pressure; HR: Heart rate; $C B C$ : Complete blood count; ABG: Arterial blood gas; ALT: Alanine aminotransferase; AST: Aspartate aminotransferase; CK: Creatine phosphokinase; BUN: Blood urea nitrogen; HF: Hydrofluoric acid; LPS: Lipopolysaccharide; IL-1ß: Interleukin-1 13; IL-6: Interleukin-6; TNFa: Tumor necrosis factor a; MCP: Monocyte chemoattractant protein; MIP-1a and MIP-2: Macrophage inflammatory protein-1a and 2; RANTES: Regulated on activation, normal T-cell expressed and secreted; NO: Nitric oxide.

\section{Acknowledgements}

We thank Ms. Kelly Byrne for editorial assistance with this manuscript. We also thank summer interns Andie WeiserSchlesinger and Thom Risoleo for their help on the project.

\section{Authors' contributions}

YL: study conception and design, performance of experiments, analysis of result, manuscript writing and revision. XC: study conception and design, performance of experiments, analysis of results, manuscript writing and revision. JS: peptidoglycan preparation and testing, manuscript revision. JW: analysis of results, manuscript revision. DS: performance of experiments, analysis of results, manuscript revision. WX: performance of experiments, manuscript revision. WL: peptidoglycan preparation and testing, manuscript revision. YF: performance of experiments, manuscript revision. JSun: statistical analysis and manuscript revision. PQE: study conception and design, performance of experiments, analysis of results, manuscript writing and revision. All authors read and approved the final manuscript.

Funding

This research was supported by the Intramural Program of the NIH, Clinical Center, Critical Care Medicine Department.

Availability of data and materials

The datasets used and/or analyzed during the current study are available from the corresponding author on reasonable request.

Ethics approval and consent to participate

Not applicable.

Consent for publication

Not applicable.

\section{Competing interests}

The authors declare that they have no competing interests.

\section{Author details}

${ }^{1}$ Critical Care Medicine Department, NIH Clinical Center, National Institutes of Health, Building 10, Room 2C145, 10 Center Drive, Bethesda, MD 20892, USA. ${ }^{2}$ Biotechnology Core Laboratory, National Institute of Diabetes, Digestive, and Kidney Diseases, National Institutes of Health, Bethesda, MD 20892, USA. ${ }^{3}$ Section of Critical Care, Department of Medicine, St. Agnes Hospital, Baltimore, MD 21229, USA.

Received: 24 June 2020 Accepted: 6 November 2020

Published online: 18 November 2020

\section{References}

1. Adalja AA, Toner E, Inglesby TV (2015) Clinical management of potential bioterrorism-related conditions. N Engl J Med 372:954-962

2. Cui X, Nolen LD, Sun J, Booth M, Donaldson L, Quinn CP, Boyer AE, Hendricks K, Shadomy S, Bothma P, Judd O, McConnell P, Bower WA, Eichacker PQ (2017) Analysis of anthrax immune globulin intravenous with antimicrobial treatment in injection drug users, Scotland, 2009-2010. Emerg Infect Dis 23:56-65

3. Sweeney DA, Hicks CW, Cui X, Li Y, Eichacker PQ (2011) Anthrax infection. Am J Respir Crit Care Med 184:1333-1341

4. Booth M, Donaldson L, Cui X, Sun J, Cole S, Dailsey S, Hart A, Johns N, McConnell P, McLennan T, Parcell B, Robb H, Shippey B, Sim M, Wallis C, Eichacker PQ (2014) Confirmed Bacillus anthracis infection among persons who inject drugs, Scotland, 2009-2010. Emerg Infect Dis 20:1452-1463

5. Remy KE, Qiu P, Li Y, Cui X, Eichacker PQ (2013) B. anthracis associated cardiovascular dysfunction and shock: the potential contribution of both non-toxin and toxin components. BMC Med 11:217

6. Sweeney DA, Cui X, Solomon SB, Vitberg DA, Migone TS, Scher D, Danner RL, Natanson C, Subramanian GM, Eichacker PQ (2010) Anthrax lethal and edema toxins produce different patterns of cardiovascular and renal dysfunction and synergistically decrease survival in canines. J Infect Dis 202:1885-1896

7. Cui X, Moayeri M, Li Y, Li X, Haley M, Fitz Y, Correa-Araujo R, Banks SM, Leppla SH, Eichacker PQ (2004) Lethality during continuous anthrax lethal toxin infusion is associated with circulatory shock but not inflammatory cytokine or nitric oxide release in rats. Am J Physiol Regul Integr Comp Physiol 286:R699-709 
8. Cui X, Li Y, Li X, Laird MW, Subramanian M, Moayeri M, Leppla SH, Fitz Y, Su J, Sherer K, Eichacker PQ (2007) Bacillus anthracis edema and lethal toxin have different hemodynamic effects but function together to worsen shock and outcome in a rat model. J Infect Dis 195:572-580

9. Coggeshall KM, Lupu F, Ballard J, Metcalf JP, James JA, Farris D, Kurosawa S (2013) The sepsis model: an emerging hypothesis for the lethality of inhalation anthrax. J Cell Mol Med 17:914-920

10. Stearns-Kurosawa DJ, Lupu F, Taylor FB Jr, Kinasewitz G, Kurosawa S (2006) Sepsis and pathophysiology of anthrax in a nonhuman primate model. Am J Pathol 169:433-444

11. Cui X, Su J, Li Y, Shiloach J, Solomon S, Kaufman JB, Mani H, Fitz Y, Weng J, Altaweel L, Besch V, Eichacker PQ (2010) Bacillus anthracis cell wall produces injurious inflammation but paradoxically decreases the lethality of anthrax lethal toxin in a rat model. Intensive Care Med 36:148-156

12. Qiu P, Li Y, Shiloach J, Cui X, Sun J, Trinh L, Kubler-Kielb J, Vinogradov E, Mani H, Al-Hamad M, Fitz Y, Eichacker PQ (2013) Bacillus anthracis Cell wall peptidoglycan but not lethal or edema toxins produces changes consistent with disseminated intravascular coagulation in a rat model. J Infect Dis 208:978-989

13. Iyer JK, Coggeshall KM (2011) Cutting edge: primary innate immune cells respond efficiently to polymeric peptidoglycan, but not to peptidoglycan monomers. J Immunol 186:3841-3845

14. Langer M, Malykhin A, Maeda K, Chakrabarty K, Williamson KS, Feasley CL, West CM, Metcalf JP, Coggeshall KM (2008) Bacillus anthracis peptidoglycan stimulates an inflammatory response in monocytes through the p38 mitogenactivated protein kinase pathway. PLoS ONE 3:e3706

15. Popescu NI, Silasi R, Keshari RS, Girton A, Burgett T, Zeerleder SS, Gailani D, Gruber A, Lupu F, Coggeshall KM (2018) Peptidoglycan induces disseminated intravascular coagulation in baboons through activation of both coagulation pathways. Blood 132:849-860

16. Iyer JK, Khurana T, Langer M, West CM, Ballard JD, Metcalf JP, Merkel TJ, Coggeshall KM (2010) Inflammatory cytokine response to Bacillus anthracis peptidoglycan requires phagocytosis and lysosomal trafficking. Infect Immun 78:2418-2428

17. Abramova FA, Grinberg LM, Yampolskaya OV, Walker DH (1993) Pathology of inhalational anthrax in 42 cases from the Sverdlovsk outbreak of 1979. Proc Natl Acad Sci USA 90:2291-2294

18. Grinberg LM, Abramova FA, Yampolskaya OV, Walker DH, Smith JH (2001) Quantitative pathology of inhalational anthrax I: quantitative microscopic findings. Mod Pathol 14:482-495

19. Twenhafel NA (2010) Pathology of inhalational anthrax animal models. Vet Pathol 47:819-830

20. Ekwunife FS, Singh J, Taylor KG, Doyle RJ (1991) Isolation and purification of cell wall polysaccharide of Bacillus anthracis (delta Sterne). FEMS Microbiol Lett 66:257-262

21. Nair AB, Jacob S (2016) A simple practice guide for dose conversion between animals and human. J Basic Clin Pharm 7:27-31

22. Briegel J, Forst H, Haller M, Schelling G, Kilger E, Kuprat G, Hemmer B, Hummel T, Lenhart A, Heyduck M, Stoll C, Peter K (1999) Stress doses of hydrocortisone reverse hyperdynamic septic shock: a prospective, randomized, doubleblind, single-center study. Crit Care Med 27:723-732

23. Minneci PC, Deans KJ, Banks SM, Eichacker PQ, Natanson C (2004) Meta-analysis: the effect of steroids on survival and shock during sepsis depends on the dose. Ann Intern Med 141:47-56

24. Petersons CJ, Mangelsdorf BL, Thompson CH, Burt MG (2014) Acute effect of increasing glucocorticoid replacement dose on cardiovascular risk and insulin sensitivity in patients with adrenocorticotrophin deficiency. J Clin Endocrinol Metab 99:2269-2276

25. van den Brink HR, van Wijk MJ, Geertzen RG, Bijlsma JW (1994) Influence of corticosteroid pulse therapy on the serum levels of soluble interleukin 2 receptor, interleukin 6 and interleukin 8 in patients with rheumatoid arthritis. J Rheumatol 21:430-434

26. Lequerre T, Farran E, Menard JF, Kozyreff-Meurice M, VandhuickT, Tharasse C, Pouplin S, Daragon A, Le Loet X, Varin R, Vittecoq O (2015) Switching from an anti-TNF monoclonal antibody to soluble TNF-receptor yields better results than vice versa: an observational retrospective study of 72 rheumatoid arthritis switchers. Joint Bone Spine 82:330-337

27. Lim MJ, Kwon SR, Joo K, Son MJ, Park SG, Park W (2014) Early effects of tumor necrosis factor inhibition on bone homeostasis after soluble tumor necrosis factor receptor use. Korean J Intern Med 29:807-813

28. Qiu P, Li Y, Ding Y, Weng J, Banks SM, Kern S, Fitz Y, Suffredini AF, Eichacker PQ, Cui X (2011) The individual survival benefits of tumor necrosis factor soluble receptor and fluid administration are not additive in a rat sepsis model. Intensive Care Med 37:1688-1695

29. Cui X, Li Y, Li X, Haley M, Moayeri M, Fitz Y, Leppla SH, Eichacker PQ (2006) Sublethal doses of Bacillus anthracis lethal toxin inhibit inflammation with lipopolysaccharide and Escherichia coli challenge but have opposite effects on survival. J Infect Dis 193:829-840

30. Erwin JL, DaSilva LM, Bavari S, Little SF, Friedlander AM, Chanh TC (2001) Macrophage-derived cell lines do not express proinflammatory cytokines after exposure to Bacillus anthracis lethal toxin. Infect Immun 69:1175-1177

31. Pellizzari R, Guidi-Rontani C, Vitale G, Mock M, Montecucco C (1999) Anthrax lethal factor cleaves MKK3 in macrophages and inhibits the LPS/IFNgamma-induced release of NO and TNFalpha. FEBS Lett 462:199-204

32. McDonald C, Inohara N, Nunez G (2005) Peptidoglycan signaling in innate immunity and inflammatory disease. J Biol Chem 280:20177-20180

33. Weidenmaier C, Peschel A (2008) Teichoic acids and related cell-wall glycopolymers in Gram-positive physiology and host interactions. Nat Rev Microbiol 6:276-287

34. Franchi L, Park JH, Shaw MH, Marina-Garcia N, Chen G, Kim YG, Nunez G (2008) Intracellular NOD-like receptors in innate immunity, infection and disease. Cell Microbiol 10:1-8

35. Loving CL, Osorio M, Kim YG, Nunez G, Hughes MA, Merkel TJ (2009) Nod1/Nod2-mediated recognition plays a critical role in induction of adaptive immunity to anthrax after aerosol exposure. Infect Immun 77:4529-4537

36. Baeuerle PA, Baltimore D (1988) Activation of DNA-binding activity in an apparently cytoplasmic precursor of the NF-kappa B transcription factor. Cell 53:211-217 
37. Fan J, Ye RD, Malik AB (2001) Transcriptional mechanisms of acute lung injury. Am J Physiol Lung Cell Mol Physiol 281:L1037-1050

38. Liu SF, Malik AB (2006) NF-kappa B activation as a pathological mechanism of septic shock and inflammation. Am J Physiol Lung Cell Mol Physiol 290:L622-L645

39. Meduri GU, Annane D, Chrousos GP, Marik PE, Sinclair SE (2009) Activation and regulation of systemic inflammation in ARDS: rationale for prolonged glucocorticoid therapy. Chest 136:1631-1643

40. Ehrchen J, Steinmuller L, Barczyk K, Tenbrock K, Nacken W, Eisenacher M, Nordhues U, Sorg C, Sunderkotter C, Roth $J$ (2007) Glucocorticoids induce differentiation of a specifically activated, anti-inflammatory subtype of human monocytes. Blood 109:1265-1274

41. Galon J, Franchimont D, Hiroi N, Frey G, Boettner A, Ehrhart-Bornstein M, O'Shea JJ, Chrousos GP, Bornstein SR (2002) Gene profiling reveals unknown enhancing and suppressive actions of glucocorticoids on immune cells. FASEB J 16:61-71

42. Rhen T, Cidlowski JA (2005) Antiinflammatory action of glucocorticoids-new mechanisms for old drugs. N Engl J Med 353:1711-1723

43. Kengatharan KM, De Kimpe SJ, Thiemermann C (1996) Role of nitric oxide in the circulatory failure and organ injury in a rodent model of gram-positive shock. Br J Pharmacol 119:1411-1421

44. Pirpiris M, Sudhir K, Yeung $S$, Jennings $G$, Whitworth JA (1992) Pressor responsiveness in corticosteroid-induced hypertension in humans. Hypertension 19:567-574

45. Fei Y, Wang W, Kwiecinski J, Josefsson E, Pullerits R, Jonsson IM, Magnusson M, Jin T (2011) The combination of a tumor necrosis factor inhibitor and antibiotic alleviates staphylococcal arthritis and sepsis in mice. J Infect Dis 204:348-357

46. Cui X, Xu W, Neupane P, Weiser-Schlesinger A, Weng R, Pockros B, Li Y, Moayeri M, Leppla SH, Fitz Y, Eichacker PQ (2019) Bacillus anthracis lethal toxin, but not edema toxin, increases pulmonary artery pressure and permeability in isolated perfused rat lungs. Am J Physiol Heart Circ Physiol 316:H1076-H1090

47. Jernigan JA, Stephens DS, Ashford DA, Omenaca C, Topiel MS, Galbraith M, Tapper M, Fisk TL, Zaki S, Popovic T, Meyer RF, Quinn CP, Harper SA, Fridkin SK, Sejvar JJ, Shepard CW, McConnell M, Guarner J, Shieh WJ, Malecki JM, Gerberding JL, Hughes JM, Perkins BA, Anthrax Bioterrorism Investigation T (2001) Bioterrorism-related inhalational anthrax: the first 10 cases reported in the United States. Emerg Infect Dis 7:933-944

48. Suffredini DA, Cui X, Xu W, Li Y, Eichacker PQ (2017) The potential pathogenic contributions of endothelial barrier and arterial contractile dysfunction to shock due to B. anthracis lethal and edema toxins. Toxins. 9:394

49. Tian Y, Mambetsariev I, Sarich N, Meng F, Birukova AA (2015) Role of microtubules in attenuation of PepG-induced vascular endothelial dysfunction by atrial natriuretic peptide. Biochim Biophys Acta 1852:104-119

50. Kumar P, Shen Q, Pivetti CD, Lee ES, Wu MH, Yuan SY (2009) Molecular mechanisms of endothelial hyperpermeability: implications in inflammation. Expert Rev Mol Med 11:e19

51. Schnoor M, Garcia Ponce A, Vadillo E, Pelayo R, Rossaint J, Zarbock A (2017) Actin dynamics in the regulation of endothelial barrier functions and neutrophil recruitment during endotoxemia and sepsis. Cell Mol Life Sci 74:1985-1997

52. Hendricks KA, Wright ME, Shadomy SV, Bradley JS, Morrow MG, Pavia AT, Rubinstein E, Holty JE, Messonnier NE, Smith TL, Pesik N, Treadwell TA, Bower WA, Workgroup on Anthrax Clinical G (2014) Centers for disease control and prevention expert panel meetings on prevention and treatment of anthrax in adults. Emerg Infect Dis. 20:e130687

53. Nakayama K, Okugawa S, Yanagimoto S, Kitazawa T, Tsukada K, Kawada M, Kimura S, Hirai K, Takagaki Y, Ota Y (2004) Involvement of IRAK-M in peptidoglycan-induced tolerance in macrophages. J Biol Chem 279:6629-6634

54. Murphey ED, Sherwood ER (2008) Pretreatment with the Gram-positive bacterial cell wall molecule peptidoglycan improves bacterial clearance and decreases inflammation and mortality in mice challenged with Pseudomonas aeruginosa. Microbes Infect 10:1244-1250

\section{Publisher's Note}

Springer Nature remains neutral with regard to jurisdictional claims in published maps and institutional affiliations.

\section{Submit your manuscript to a SpringerOpen ${ }^{\circ}$ journal and benefit from:}

- Convenient online submission

- Rigorous peer review

- Open access: articles freely available online

- High visibility within the field

- Retaining the copyright to your article

Submit your next manuscript at $\boldsymbol{\Delta}$ springeropen.com 